\title{
Changes in the Structure of International Trade And Services in the Context of Tax Fraud and Tax Evasion
}

\author{
Antonín Korauš ${ }^{1}$, Miroslav Gombár ${ }^{2}$, and Filip Černák ${ }^{2}$ \\ ${ }^{1}$ Academy of the Police Force in Bratislava, Sklabinská 1, 83517 Bratislava 35, Slovak Republic \\ ${ }^{2}$ University of Prešov in Prešov, Faculty of Management, Konštantínova 16, 08001 Prešov, Slovak \\ Republic
}

\begin{abstract}
The EU and the Member States have been forced in recent years to take a stronger position against the growing trend of tax fraud, tax evasion, and tax avoidance. The EU legislative and non-legislative acts in this area have resulted from political attitudes, economic intentions, proposals, and compromises reached between the individual Member States, on the one hand, and the EU, on the other, in their effort to combat fraudulent behaviour in the taxation area. The fight against fraudulent behaviour in the taxation area, be it tax fraud, tax evasion or tax avoidance, has become a real global challenge not only for the EU and its Member States but also for the entire world. These are different forms and methods for misusing tax systems both within the EU and abroad. This paper is part of the project: "Electronic methods for detecting unusual business transactions in the business environment" (ITMS code: 313022W057), cofinanced by the European Regional Development Fund (ERDF) and also the project "VEGA1 / 0194/19 - Research on process-oriented financial management with a focus on to detect tax evasion in international trade". Keywords: international trade, international services, tax fraud, tax evasion.
\end{abstract}

\section{Introduction}

The fight against the misuse of the tax system in the eyes of the EU law is undoubtedly a very up-to-date topic and, at the same time, a very complex and sensitive one. This applies to indirect taxes (in particular VAT) and direct taxation $[1,2]$. In this context, it should be emphasised that ever since the European Commission has defined the terms tax fraud and tax evasion, the notion of tax fraud seems to be "linked" to the VAT system, and also consumer taxes, or more aptly, it is linked to the misuse of the indirect taxation system. Consequently, tax evasion is "directly linked" to the income tax [3].

In the context of VAT tax fraud, this is ultimately a evasion of VAT tax, thus causing losses in the state budget revenue. Such evasion, however, may not necessarily result from

\footnotetext{
* Corresponding author: antonin.koraus@akademiapz.sk
} 
the tax fraud committed by a tax entity within the applicable system of VAT application, which is the object of interest for the criminal law.

A similar situation applies when considering tax evasions resulting from a tax entity's illegal conduct or behaviour. In this case, too, we may state that, in the eyes of the tax law and even of the criminal law, this is a tax fraud de facto, even though it is not directly related to the issue of indirect taxation. It is pretty understandable that the term tax fraud applies to the VAT system. As pointed out by the European Commission, the EU VAT system benefits the single market, as it has removed barriers distorting competition and hindering the free movement of goods, thus greatly facilitating trade in the EU [4, 19]. As a broad-based consumption tax, VAT is considered one of the best forms of taxation that stimulates growth. It is also a significant and growing source of tax revenue within the EU [5].

\section{Management of the elimination of severe tax evasions and fraud}

Given that the management of the elimination of severe tax evasions and fraud is linked to the European territory and concerning the importance of this issue in the European and global context, it is necessary to look for the causes and existence of tax evasions and then look for ways to eliminate them using appropriate management measures $[6,18]$. The importance within the society of the theoretical and subsequent practical outputs in this area has been growing and affects the economics, law, economy, and international rating of countries.

Whatever aspect we chose to assess the quality and effectiveness of the fight against misuse of the tax system, we would always come to the following conclusions:

- misuse of the tax system consists of separately perceived infringements that take tax fraud, tax evasion, and tax avoidance. In most cases, the nature of these infringements is in contrast with the rules laid down in the relevant tax legislation which govern the prohibition of the misuse of tax law;

- in practical terms, tax fraud may not be separated from tax evasion or tax avoidance. In this context, it should be emphasised that, in the eyes of the criminal law, tax fraud is understood as intentional and illegal tax evasion;

- due mainly to the political decisions taken by the European Commission, tax frauds are linked to the issue of indirect taxation, and they also affect the amount of state budget revenue from taxes in any state due to income tax;

- VAT tax frauds are not/do not have to necessarily result from the tax fraud committed by a tax entity. In this context, it can be stated that even an illegal tax evasion is, a de facto tax fraud in the eyes of the tax law.

- in an economic and political alliance, such as the EU, one cannot view the concerted EU efforts to combat VAT fraud separately from the Member States' efforts in this area. Without clearly demonstrated will of all EU Member States, the Union as a whole would not have achieved any "more tangible" success in the fight against tax fraud, tax evasion and other tax infringements;

- the interests of EU Member States in combatting the misuse of the tax system often differ from the EU interests, as demonstrated by the complex nature of the procedures to reach unanimous agreement when adopting EU legislation in this area;

- it would be appropriate to explicitly state in the EU legislative and non-legislative acts, in the political documents issued by the public authorities, in explanatory memoranda to tax laws, etc., that a distinction must be made for the term "tax evasion": 
- tax evasion sensu stricto, as a result of illegal/legal conduct and behaviour of tax entities in the field of income taxation, by which the tax entities reduce/eliminate their tax liability to the state budget;

- tax evasion sensu largo, as a result of reduction/loss of state budget tax revenues due to tax fraud, tax evasion sensu stricto and/or tax avoidance.

Tax fraud has posed a massive problem in the operation of the EU throughout the EU's existence which continues to this day. This particularly applies to VAT frauds which undermine the smooth operation of the EU internal market [7]. On the other hand, it would be very misleading for us to conclude that the EU institutions have neglected their responsibilities in the fight against tax fraud. Instead, their interest was not primarily focused on taking adequate measures to prevent tax fraud, and they focused on the subsequent resolution of the ensuing problems $[8,20]$.

Regardless of the subject of the taxation, VAT tax fraud may take various forms and features. These may include wilful conduct or inaction of the tax entity (e.g. by their failure to file a tax return, etc.). However, VAT frauds are primarily associated with tax entities' active and mostly intentional conduct $[9,17]$.

According to a report published by the European Court of Auditors (ECA), the exchange of tax information between the Member States is still insufficient to ensure fair and efficient taxation within the entire single market. There are problems not only in the EU legislative framework but also in its implementation and monitoring. In particular, the auditors found numerous cases of poor quality of the information being exchanged or that the information was not utilised to the necessary extent.

The ever-increasing number of cross-border transactions complicates the proper evaluation of tax obligations by the Member States and provides room for avoiding tax obligations and for tax evasion. The revenue losses from tax avoidance alone by legal entities are estimated to range from $€ 50$ billion to $€ 70$ billion in the EU. If special tax rules and inefficient tax collection are included in this estimate, the above amount will increase to almost $€ 190$ billion. Therefore, cooperation between the Member States is essential to collect the total amount of taxes on time.

Value-added tax is one of the indirect taxes, which means that this tax is paid indirectly, i.e. in the price of goods and services. The specific nature of the value-added tax lies in the fact that the entity which collects and pays the tax to the state budget (i.e. the taxpayer) and the entity which pays this tax is not the same person, namely because:

- the entity collecting and paying this tax is a legal or natural person - entrepreneur (VAT payer),

- the entity paying this tax is the final consumer (customer) who pays the VAT in the price of the goods or services.

Every year in the EU, billions of euros are lost to tax evasion. Efforts by national tax authorities to tackle this are increasingly hampered by new business models, especially those based on digital technology.

Tax-compliant businesses also need a more straightforward and more up-to-date tax system if they are to benefit from the single market. This action plan presented key initiatives to:

- tackle tax fraud,

- make compliance easier,

- take advantage of the latest developments in technology and digitalisation.

According to a new special report published by the European Court of Auditors (ECA), there is still insufficient sharing of tax information between the EU Member States to ensure fair and effective taxation throughout the Single Market. The problems are not only with the EU's legislative framework but also with its implementation and monitoring. In particular, the auditors found that, often, the information exchanged is of limited quality or 
underused. The ever-growing number of cross-border transactions makes it difficult for the Member States to assess taxes due properly and encourages tax avoidance and evasion. Revenues lost to corporate tax avoidance alone are estimated at between $€ 50$ billion and $€ 70$ billion yearly in the EU, reaching some $€ 190$ billion if special tax arrangements and tax collection inefficiencies are included. Cooperation between the Member States is essential to make sure taxes are collected in full and due.

The legislative framework the European Commission has established for the exchange of tax information is transparent and logical. However, it suffers from several gaps, warn the auditors. Firstly, it remains incomplete concerning stemming tax avoidance and evasion. Cryptocurrencies, but also other forms of income, for instance, are not subject to mandatory reporting, thus remaining largely untaxed. Secondly, the support provided to the Member States does not go far enough. In particular, the Commission barely addresses the issue of poor data quality and does not assess how effective and deterrent the sanctions for non-compliance are. Finally, the Commission should provide more guidance to help the Member States, especially in data analysis and use [10].

The national governments of the EU Member States are broadly free to design their tax laws and systems, and decision making in this policy sensitive area at an EU level requires the agreement of all Member States. However, all national legislation must respect certain fundamental principles, such as non-discrimination and freedom of movement in the internal market. The tax laws of one country should not allow people to escape taxation in another.

Member States in their turn must:

- operate the taxation systems;

- collect and report the required tax-related information;

- share best practices;

- ensure fair tax competition in the internal market.

Many countries have agreed to lift bank secrecy for tax purposes, share tax information with other governments and remove the secrecy surrounding the owners, banking arrangements and financial transactions of legal entities. The starting point was the global EOIR standard developed by the OECD, which first provided for information to be exchanged internationally between two countries at the tax authority's request, with a new requirement added to obtain and exchange information even if held by a bank. Technological advances have also led to the widespread automatic exchange of information, complementing EOIR.

\section{Conclusion}

The implemented legislative measures also form an essential aspect of the elimination of tax evasion in that they helped transform the behaviour of taxpayers, increase their discipline and help form their responsible approach to the selection of business partners. As a negative side effect, the approaches and variability of tax evasion and frauds have become more diverse and more sophisticated.

Legislative tax measures have translated into an increase in state budget revenues, which positively affected the achievement of fiscal policy objectives, especially in reducing the GDP deficit. Increasing the efficiency of tax collection and the identification and elimination of tax evasion and fraud is a long-term process. The importance of adopting a permanent and effective solution to address tax evasion and fraud is possible through a combination of cooperation and legislative measures with an emphasis on tax law. Legislative tax standards create room for implementing tax planning, tax optimisation and, from an opposing point of view, this also provides an opportunity for aggressive tax planning, even creation and use of schemes to commit tax evasion and fraud[11]. 
Over the past years, the EU and the Member States have been forced to take a stronger position against the growing trend of tax fraud, tax evasion and tax avoidance. [12] The EU legislative and non-legislative acts in this area have resulted from political attitudes, economic intentions, proposals and compromises reached between the individual Member States, on the one hand, and the EU, on the other, in their effort to combat tax fraud [13].

As stated by [14], the fight against tax fraud, be it tax fraud, tax evasion or tax avoidance, has become a real global challenge not only for the EU and its Member States but also for the entire world. These are different forms and methods for misusing tax systems both within the EU and abroad.

In the eyes of the EU law, the fight against the misuse of the tax system is currently a crucial, complex and susceptible topic. This does not apply to indirect taxes only, in particular VAT, but also to direct taxation.

Tax fraud and tax evasion have been and are likely to continue to represent a significant issue throughout the existence of the EU [15]. This is particularly true in VAT, as this issue distorts the law's correct and well-functioning EU internal market. However, we cannot state that the EU institutions have neglected their obligations to fight against tax fraud. Rather than addressing and preventing causes, the institutions dealt with the consequences. Adequate measures were not taken as a matter of priority to prevent tax fraud; instead, they focused on the consequences and thus addressed the following issues. It should be emphasised that VAT evasion is a fundamental problem in tax administration regarding the scope, forms, methods or procedures and one that needs to be resolved by the tax administrations in the individual EU Member States.

At the beginning of 2020 , the world was hit by a situation which no one expected. Coronavirus pandemic has affected most countries around the globe and caused significant changes in the economy and social life of the countries and in the life of every single citizen. The pandemic seriously disrupted and changed conditions for doing business, the structure and volume of services worldwide. E-commerce is no exception, even though at first glance, it might seem that it was and will be affected to a lesser extent than other areas. The operations of numerous companies in China, Europe or the US have virtually stopped, even though e-commerce continues to operate and the pandemic has had a different impact on its functioning [16]. At the same time, various general measures are adopted in individual countries, which follow up on their risk management strategies, critical security assets, risk mitigation priorities, etc. Subsequently, the strategies are re-evaluated in the area of healthcare, providing supplies to the general public, conditions of doing business, mobility and provision of services.

Based on the available information, we can see that the coronavirus pandemic affects the shopping behaviour of customers and corporate entities. The search rankings have changed significantly for the most popular products in the e-commerce of natural persons. The focus of attention has moved to products that are most important for people's lives (food) or those helping to overcome quarantine or social exclusion and restrictions on freedom of movement (board games, sports equipment, etc.).

In general, there has been an increase in the online sales of products, although it is not yet possible to recognise a clear trend in the long run. However, we can state that the customers started to use online shopping to a greater extent. From a consumer behaviour perspective, this may also result in increased trust in online shopping, potentially leading to e-commerce revenue growth even after the coronavirus pandemic. However, to analyse every impact of the pandemic on e-commerce, we will need to explore additional changes in the economy and social life of individual countries and put them in relation to the time, space and content of individual quarantine measures, especially as regards the security of activities in the online environment. In the coronavirus pandemic, there is an increased possibility for the misuse of cyberspace for unfair and fraudulent practices and activities, 
which the perpetrators of such activities also used. The business environment is no exception, and the number of cyberattacks, fraud and other criminal activities is on the rise.

This publication has been written thanks to the support of the Operational Programme Integrated Infrastructure for the project: "Electronic methods for detecting unusual business transactions in a business environment" (ITMS code: 313022W057), co-funded by the European Regional Development Fund (ERDF) and also by the "VEGA1/0194/19-Research on process-oriented management of financial management focusing on detection of tax evasion in terms of international business".

\section{References}

1. B. Salanié, The Economic of Taxation, (MIT Press, Cambridge, UK, ISBN: 0-26219486-4, 2003).

2. M. Schratzenstaller, Obs. Diagn. Econ. 141, 55-77. https://www.ofce.sciencespo.fr/pdf/revue/3-141.pdf. (2015)

3. K. Krzikallová, F. Tošenovský, Sustainability, 12, 4925. https://doi.org/10.3390/su12124925 . (2020)

4. European Commission :VAT Rates Applied in the Member States of the European Union. Situation at 1st January 2020; EuropeanCommission: Brussels, Belgium. (2020)

5. M.Keen, B. Lockwood, Journal of Development Economics. 92(2), 138-151.DOI: 10.1016/j.jdeveco.2009.01.012 (2009)

6. S. Cnossen, International Tax and Public Finance, 25, 519-551. https://doi.org/10.1007/s10797-017-9453-4 (2018)

7. M. Bonucchi, M.Ferrari, S.Tomasini, T.Tsvetomira, Revue de l'OFCE, 141(5), 225262. https://www.cairn.info/revue-de-1-ofce-2015-5-page-225.htm\#citepar (2015)

8. A. Kowal, Zeszyty Naukowe Małopolskiej Wyższej Szkoły Ekonomicznej W Tarnowie, 44(4), 39-51. https://doi.org/10.25944/znmwse.2019.04.3951 (2019).

9. G. Sobiecki, M. Szwed-Ziemichód, Analizy i Studia 1, 3-33. DOI: https://doi.org/10.33119/ASCASP.2019.1.1 (2019)

10. Special report 03/2021: "Exchanging tax information in the EU: solid foundation, cracks in implementation" is available on the ECA website (eca.europa.eu) in 23 EU languages. https://op.europa.eu/webpub/eca/special-reports/tax-03-2021/sk/ (2021)

11. A. Andrejovská, V. Konečná, J. Hakalová, Ad Alta J. Interdiscip. Res. 10, 8-13. ISSN: 1804-7890, 2464-6733. (2020).

12. M. Feldek, Financial Law Review, 20, 35-52. ISSN: 2299-6834. DOI: 10.4467/22996834FLR.20.019.13091 . (2020).

13. G. Poniatowski, M.Bonch-Osmolovskiy, J.M.Durán-Cabré, A.Esteller-Moré, A. Smietanka, Studyand Reports on the VAT Gap in the EU-28 Member States: Final Report. Available online: http://case-research.eu/files//?id_plik=5692. (2018).

14. M.Bernasconi, L.Corazzini, R. Seri, Journal of Economic Psychology, 40, 103-118. DOI: 10.1016/j.joep.2013.01.005 . (2014).

15. B. Timmermans, W.M.J. Achten. Int J Life Cycle Assess 23, 2217-2247. https://doi.org/10.1007/s11367-018-1439-7. (2018).

16. M.Sikandar. Mapping The Impact Of COVID-19 Pandemic On E-Commerce. Available at: https://cedcommerce.com/blog/impact-of-covid-19-on-ecommerce/ (2020). 
17. L. Mura, J. Buleca, Procedia Economics and Finance, 3, pp.217-222. (2012)

18. L. Mura, Z. Hajduová, Entrepreneurship and Sustainability Issues, 8(3), 487-503. https://doi.org/10.9770/jesi.2021.8.3(31). (2021).

19. M. Srebalova, M. Horvath, J. Vacok, F. Vojtech, S. Filip, Entrepreneurship and Sustainability Issues, 7(4), 3385-3394, https://doi.org/10.9770/jesi.2020.7.4(53). (2020).

20. D. Novackova, T. Peracek, L. Strazovska, B. Much, Juridical Tribune - Tribuna Juridica, 10, 142-163. (2020).

21. O. Prokopenko et al. International Journal of Scientific and Technology Research, 9(3), pp. 1112-1115. (2020).

22. O. Prokopenko, V. Omelyanenko, TEM Journal, 9 (3), pp. 1068-1075. DOI: 10.18421/TEM93-31. (2020). 